\title{
Association Studies of Different Genetic Variants of aS2-casein Gene (CSN1S2) With Milk Production Traits (Lactose, SNF\&Density) in Malvi, Nimari, Sahiwal \& HF Crossbred Cattle
}

\author{
Akhilesh Pandey \\ College of Veterinary Science and Animal Husbandry Mhow \\ Zeeshan Khan ( $\nabla$ khanzeeshan32@gmail.com ) \\ College of Veterinary Science and Animal Husbandry Mhow https://orcid.org/0000-0003-2732-207X
}

\section{Research Article}

Keywords: Malvi, Nimari, Sahiwal, HF crossbred, Polymorphism, as2Casein Gene

Posted Date: October 19th, 2021

DOl: https://doi.org/10.21203/rs.3.rs-984891/v1

License: (a) (1) This work is licensed under a Creative Commons Attribution 4.0 International License.

Read Full License 


\section{Abstract}

as2-casein is a primary milk protein. However, there has been little research focused on the effects of as2casein variants on milk. The as2-casein (CSN1S2) play a major protein found in ruminant's milk, which is encoded by a highly polymorphic CSN1S2 gene present on chromosome 6. Research work was carried out on 50 animals each of Malvi, Nimari, Sahiwal and HF Crossbred cattle at Jabalpur, Madhya Pradesh, India. The aS2 casein gene (1267 bp) was digested by EcoRV restriction enzyme yielding two genotypes viz., AA (1267 bp) and BB (1267/1150/117 bp) in Malvi, Nimari and HF crossbred cattle, while only one genotype (AA) in Sahiwal. The restriction site was absent in Sahiwal resulting in only single compact band of $1267 \mathrm{bp}$. The tested animals of Sahiwal were found monomorphic at this locus. Association study of different genotypes with milk composition traits revealed that the mean lactose \% was significantly higher in Malvi compared to others for $A B$ genotype animals as compared to AA genotype. The mean SNF \% between AA and AB was found non-significant in Malvi, Nimari and HF crossbred. The mean milk density $(\mathrm{kg} / \mathrm{L})$ was significantly higher for $A B$ genotype than $A A$ genotype of Nimari and HF crossbred. The mean milk density $(\mathrm{kg} / \mathrm{L})$ was observed maximum in Nimari for $A B$ genotype and minimum in Malvi and Sahiwal for AA genotype. The genotypic and gene frequencies of aS2-casein gene (CSN1S2)/EcoRV locus pattern showed that the frequencies of $A A, A B$ and $B B$ genotypes were found to be $0.44,0.56$ and 0.00 in Malvi; $0.68,0.32$ and 0.00 in Nimari; 1.00, 0.00, and 0.00 in Sahiwal and 0.58, 0.42 and 0.00 in HF crossbred, respectively. The frequency of $A$ allele was found to be highest as compared to B allele in all the four breeds of cattle under the study.

\section{Introduction}

aS2 Casein genes are highly polymorphic and the high degree of variability has qualitative and quantitative effects on milk composition thereby affecting chemical, physical and technological properties of goat milk. The aim of this work was to evaluate the genetic polymorphisms of the as2casein (CSN1S2) gene and its association with different milk production traits in Malvi, Nimari, Sahiwal and HF Crossbred cattle. Caseins are the main protein component of milk. In bovine species the entire casein gene cluster region spans about 250 kb on chromosome 6 (Hayes et al., 1993). Casein genes are highly polymorphic and the high degree of variability, together with post-translational modifications and differential splicing patterns, has qualitative and quantitative effects on milk composition. In cattle, at least 39 variants of the 4 casein proteins ( $\mathrm{aS} 1-, \beta$-, aS2- and k-casein) have been described to date. Many of these variants are known to affect milk-production traits, cheese-processing properties, and the nutritive value of milk. They also provide valuable information for phylogenetic studies. So far, the majority of studies exploring the genetic variability of bovine caseins considered European taurine cattle breeds and were carried out at the protein level by electrophoretic techniques. This only allows the identification of variants that, due to amino acid exchanges, differ in their electric charge, molecular weight, or isoelectric point.

\section{Materials And Methods}




\subsection{Collection of milk samples with economic traits}

About $100 \mathrm{ml}$ milk sample was collected from each of the above 200 cattle. The milk samples brought to the laboratory, maintaining cold chain and then Lactose (\%), SNF (\%) and Milk density (Kg/L) were determined.

\subsection{Estimation of Lactose (\%), SNF (\%) and Milk density $(\mathrm{Kg} / \mathrm{L})$}

The Lactose (\%), SNF (\%) and Milk density $(\mathrm{Kg} / \mathrm{L})$ were analyzed by Milk analyzer of the Department of Veterinary Medicine, College of Veterinary Science \& A.H., Jabalpur.

\subsection{Blood Collection}

$5 \mathrm{ml}$ blood sample was collected in EDTA coated vaccutainer aseptically from 50 animals of each of the four breeds viz. Malvi, Nimari, Sahiwal and HF crossbred cattle and brought to the laboratory, maintaining cold chain then processed for DNA isolation.

\subsection{Genomic DNA isolation:}

Genomic DNA was extracted from venous blood as per the method described by John et al. (1991) with minor modifications.

\subsection{Agarose gel electrophoresis:}

Quality of DNA was assessed through $0.80 \%$ horizontal submarine agarose gel electrophoresis.

\subsection{Concentration, purity and quality check of DNA}

The concentration, purity and quality of DNA were checked by Nanodrop spectrophotometer and agarose gel electrophoresis.

\subsection{Spectrophotometry}

The concentration, purity of DNA was checked by Nanodrop Spectrophotometer. The Optical density (OD) value at $260 \mathrm{~nm}$ and $280 \mathrm{~nm}$ was measured using Nanodrop Spectrophotometer (Nanodrop 1000, Thermo Scientific). DNA samples with an OD 260/280 ratio of 1.70 to 1.90 were considered further subjected to agarose gel electrophoresis for quality check. The DNA concentration was determined and samples were diluted up to approximate $30 \mathrm{ng} / \mu \mathrm{l}$ for final concentration with sterile nuclease free water (MiliQ) for further use.

\subsection{Casein gene primer sequence:}

The aS2-casein gene primers (F): 5'-TATGACATGTCGAGAAATGAG-3'

(R): 5'-TTGGAACAATGCTATTAGGT T- 3'1267 bp (Szymanowska et al. 2003) was used for the amplification of PCR product. 


\subsection{Polymerase Chain Reaction (PCR) \\ 2.9.1. Setting of PCR Reaction}

The PCR tubes were kept in a preprogrammed thermo cycler (Mastercycler gradient, Eppendorf) and set at the standardized reaction programme. Initial denaturation (5 minutes) and final denaturation(1 minute) temp. Was $94^{\circ} \mathrm{C} 600 \mathrm{C}$ anniling temp.( $1 \mathrm{~min}$.) Was $600 \mathrm{C}$ where extension( 1 minute) and final extension(5 minutes) temp. was $720 \mathrm{C}$

\subsubsection{Agarose gel electrophoresis of PCR reaction product}

To confirm the targeted PCR amplification the PCR products were analyzed on $2.00 \%$ agarose gel. The mass ruler DNA ladder (100 bp- 1000 bp) as a molecular size marker was used for sizing of the DNA bands.

\subsection{PCR- RFLP Assay \\ 2.10.1 Restriction digestion:}

All the PCR products of as 2 casein gene were digested by EcoRV restriction enzymes. The reaction mixture was spanned for few seconds for uniform mixing and then incubated at $37^{\circ} \mathrm{C}$ for $3 \mathrm{hrs}$ in the water bath.

Table 01: PCR - RFLP profile

\begin{tabular}{|c|c|c|c|c|c|}
\hline $\begin{array}{l}\text { S. } \\
\text { No. }\end{array}$ & $\begin{array}{l}\text { Casein } \\
\text { Gene }\end{array}$ & $\begin{array}{l}\text { Restriction } \\
\text { Enzyme }\end{array}$ & Restriction Site & Base Pair & $\begin{array}{l}\text { RFLP } \\
\text { product }\end{array}$ \\
\hline 01 & as 2 & EcoRV & $\begin{array}{l}5^{\prime} \ldots \text { GATATC } \ldots . .3^{\prime} \\
3^{\prime} \ldots \text { CTATAG .......5 }\end{array}$ & $1267 \mathrm{bp}$ & $\begin{array}{l}1267 \mathrm{bp} \\
1150 \mathrm{bp} \\
117 \mathrm{bp}\end{array}$ \\
\hline
\end{tabular}

\subsubsection{Agarose gel electrophoresis of digested PCR products:}

Digested PCR products were analyzed on $2.50 \%$ agarose gel ( $5 \mu \mathrm{l}$ of PCR product mixed with $1 \mu \mathrm{l}$ of gel loading dye). The mass ruler DNA ladder (100 bp- $1000 \mathrm{bp}$ ) as a molecular size marker was used for sizing of the DNA bands. 


\subsection{Sequencing:}

Sequencing of amplicon was done for the confirmation of genotype of the cattle. The sequences obtained from genotype were aligned using Clustal W (Thompson et al., 1994) and analyzed by using MEGA 6 software (Tamura et al., 2004). Aligned sequences were analyzed for group specific SNP marker.

\subsection{Statistical analysis:}

\subsubsection{Calculation of Gene and genotype frequencies}

Gene and genotype frequencies for different casein genes under study were estimated using Popgene 32 (version1.32), microsoft Windows-based freeware for population genetic analysis (Yeh et al., 1999).

\subsubsection{Association of various polymorphic variants of milk protein genes with Lactation length (LL)}

Association study of various polymorphic variants of milk protein genes for lactation length data were subjected to least squares analysis of variance employing following linear model:

$Y i j k l=\mu+P i+B j+G k+(P X B) i j+(P X G) i k+(B X G) j k+(P X B X G) i j k+e i j k l$

Where,

Yijkl - is the Observed value of milk yield

$\mu$ - is the population mean

$\mathrm{Pi}$ - is the fixed effect of parity

$\mathrm{Bj}$ - is the fixed effect of breed

Gk - is fixed effect of genotypes $(k=1,2 \ldots$.

(PXB)ij- is interaction effect of parity and Breed

(PXG)ik - is interaction effect of parity and genotypes

(BXG)jk - is interaction effect of Breed and genotypes

(PXBXG)ijk - is interaction effect of parity, breed and genotypes

eijkl - is random error effect 


\subsubsection{Testing Hardy-Weinberg (H-W) equilibrium}

The chi-square test ( $\left.x_{2} 2\right)$ was employed to test the status of Hardy-Weinberg equilibrium in the different population of four breeds of cattle (Snedecor and Cochran, 1994).

\subsubsection{Regression between various traits (Milk yield and Milk composition traits) for different genotypes breeds wise.}

To find out the association between the polymorphic variants/ genotypes of, $\beta$-casein genes with milk production traits like, Milk yield (MY), Daily milk yield (DMY), Protein (\%), Fat (\%), Lactose (\%), SNF (\%) and Milk density $(\mathrm{Kg} / \mathrm{L})$ in of Sahiwal and HF crossbred cattle by linear regression model was employed.

\section{Results}

The genotypic and gene frequencies of aS2-casein gene (CSN1S2)/EcoRV locus in Malvi, Nimari, Sahiwal and HF crossbred cattle has been presented in table 26. The frequencies of $A A, A B$ and $B B$ genotypes were found to be $0.44,0.56$ and 0.00 in Malvi; $0.68,0.32$ and 0.00 in Nimari; $1.00,0.00$, and 0.00 in Sahiwal and $0.58,0.42$ and 0.00 in HF crossbred cattle, respectively. The respective gene frequency for $A$ and $B$ alleles were found to be 0.72 and 0.28 in Malvi; 0.84 and 0.16 in Nimari; 1.00 and 0.00 in Sahiwal and 0.79 and 0.21 in HF crossbred cattle. The frequency of $A$ allele was found to be highest as compared to $B$ allele in all the four breeds of cattle under the study.

During the sequence analysis of amplicon for group specific SNP marker following results was noticed:

i. Adenine base at 242 base pair site in HF Crossbred replaced by Thymine in Nimari breed of cattle of Madhya Pradesh.

ii. In HF Crossbred at 582 base position of Adenine base is replaced by Guanine in Malvi, Nimari and Sahiwal breeds of Cattle.

iii. In Malvi and HF Crossbred at 715 base position of Thymine base is replaced by Cytosine in Nimari breed and 713 base position of Thymine base in Malvi and HF Crossbred is replaced by Cytosine in Sahiwal breeds of Cattle.

\section{ASSOCIATION STUDY:}

LACTOSE (\%) OF DIFFERENT VARIANTS AT AS2-CASEIN GENE (CSN1S2)/ ECORV LOCUS IN FOUR BREEDS OF CATTLE:

The analysis of variance for different genotypes of four breeds of cattle breed has been presented in Table 02. The effect of genotypes was found significant $(P<0.01)$ for lactose $(\%)$ trait. The mean lactose 
per cent in the milk of Malvi, Nimari, Sahiwal and HF crossbred cattle has been presented in Table 03.

Table 02

Least squares analysis of variance for Lactose

(\%) in the milk of different breeds of cattle at aS2-Casein (CSN1S2) gene locus.

\begin{tabular}{|llll|}
\hline Source of Variance & DF & MS & F-value \\
\hline Genotypes & 6 & 2.35 & $9.75^{\star \star}$ \\
\hline Error & 193 & 0.24 & \\
\hline Total & 199 & & \\
\hline
\end{tabular}

The effect of genotypes was found significant $(\mathrm{P}<0.01)$ for lactose $(\%)$ trait. The mean lactose per cent in the milk of Malvi, Nimari, Sahiwal and HF crossbred cattle has been presented in following table.

Table 03

Least squares means for Lactose (\%) in the milk of different breeds of cattle at aS2-Casein (CSN1S2) gene locus.

\begin{tabular}{|lllll|}
\hline Variants & Breeds & & & \\
\cline { 2 - 5 } & Malvi & Nimari & Sahiwal & HF crossbred \\
\hline AA & $4.73^{\mathrm{d}} \pm 0.09$ & $5.46^{\mathrm{ab}} \pm 0.04(31)$ & $5.25^{\mathrm{b}} \pm 0.07$ & $5.35^{\mathrm{b}} \pm 0.10$ \\
& $(22)$ & & $(50)$ & $(29)$ \\
\hline AB & $5.02^{\mathrm{c}} \pm 0.08$ & $5.72^{\mathrm{a}} \pm 0.18$ & $0.00 \pm 0.00$ & $5.44^{\mathrm{ab}} \pm 0.09$ \\
& $(28)$ & $(19)$ & $(00)$ & $(21)$ \\
\hline BB & $0.00 \pm 0.00$ & $0.00 \pm 0.00$ & $0.00 \pm 0.00$ & $0.00 \pm 0.00$ \\
& $(00)$ & $(00)$ & $(00)$ & $(00)$ \\
\hline Overall & $4.89^{\mathrm{c}} \pm 0.06$ & $5.56^{\mathrm{a}} \pm 0.07$ & $5.25^{\mathrm{b}} \pm 0.07$ & $5.39^{\mathrm{ab}} \pm 0.07$ \\
& $(50)$ & $(50)$ & $(50)$ & $(50)$ \\
\hline
\end{tabular}

Means bearing the different superscript differ significantly $(p<0.01)$, Numbers in the parentheses denotes number of animals

As shown in Table 03, the mean lactose per cent was significantly higher in Malvi and non-significantly higher in Nimari and HF crossbred for AB genotyped animals as compared to AA genotype. Among the 
different genotypes of all four breeds of cattle, higher protein per cent was recorded in Nimari $(5.72 \pm 0.18)$ for $A B$ genotyped animals, while it was found significantly lower in Malvi $(4.73 \pm 0.09)$ cattle for $A A$ genotype (Table 03).

\section{SNF (\%) OF DIFFERENT VARIANTS AT aS2-CASEIN GENE (CSN1S2) / ECORV LOCUS IN FOUR BREEDS OF CATTLE:}

The analysis of variance for different genotypes of four breeds of cattle breed has been presented in Table 04. The effect of genotypes was found significant $(P<0.01)$ for SNF $(\%)$ trait. The mean SNF per cent in the milk of Malvi, Nimari, Sahiwal and HF crossbred cattle has been presented in Table 05.

Table 04: Analysis of variance for SNF (\%) in Malvi, Nimari, Sahiwal and HF Crossbred cattle

\begin{tabular}{|l|c|c|c|}
\hline Source of Variance & DF & MS & F-value \\
\hline Genotypes & 6 & 3.53 & $5.69^{* *}$ \\
\hline Error & 193 & 0.62 & \\
\hline Total & 199 & & \\
\hline
\end{tabular}

** Highly significant $(\mathrm{p}<0.01)$

Table 05: Least squares means for SNF (\%) in the milk of different breeds of cattle at $\propto$ S2-Casein (CSN1S2) gene

\begin{tabular}{|l|c|c|c|c|}
\hline Variants & \multicolumn{4}{|c|}{ Breeds } \\
\cline { 2 - 5 } & Malvi & Nimari & Sahiwal & HF crossbred \\
\hline AA & $7.86^{\mathrm{c}} \pm 0.16$ & $8.86^{\mathrm{a}} \pm 0.15$ & $8.74^{\mathrm{a}} \pm 0.12$ & $8.47^{\mathrm{ab}} \pm 0.10$ \\
& $(22)$ & $(31)$ & $(50)$ & $(29)$ \\
\hline $\mathrm{AB}$ & $8.17^{\mathrm{bc}} \pm 0.13$ & $8.81^{\mathrm{a}} \pm 0.23$ & $0.00 \pm 00$ & $8.63^{\mathrm{a}} \pm 0.14$ \\
& $(28)$ & $(19)$ & $(00)$ & $(21)$ \\
\hline $\mathrm{BB}$ & $0.00 \pm 00$ & $0.00 \pm 0.00$ & $0.00 \pm 0.00$ & $0.00 \pm 0.00$ \\
& $(00)$ & $(00)$ & $(00)$ & $(00)$ \\
\hline Overall & $8.03^{\mathrm{b}} \pm 0.11$ & $8.84^{\mathrm{a}} \pm 0.13$ & $8.74^{\mathrm{a}} \pm 0.12$ & $8.54^{\mathrm{a}} \pm 0.08$ \\
& $(50)$ & $(50)$ & $(50)$ & $(50)$ \\
\hline
\end{tabular}

Means bearing the different superscript differ significantly $(\mathrm{p}<0.01)$, Numbers in the parentheses denotes number of animals

The mean SNF per cent between AA and AB was found non-significant in Malvi, Nimari and HF crossbred cattle. In Sahiwal, only AA genotype was identified with 8.74 \pm 0.12 per cent SNF. The mean SNF per cent was recorded maximum in Nimari $(8.86 \pm 0.15)$ and minimum in Malvi $(7.86 \pm 0.16)$ for AA genotyped animals among all the four breeds of cattle (Table 05). 


\section{DENSITY (KG/L) OF DIFFERENT VARIANTS AT AS2-CASEIN GENE (CSN1S2)/ ECORV LOCUS IN FOUR BREEDS OF CATTLE:}

The analysis of variance for different genotypes of four breeds of cattle breed has been presented in Table 06. The effect of genotypes was found significant $(P<0.01)$ for milk density $(\mathrm{kg} / \mathrm{L})$ trait. The mean milk density $(\mathrm{kg} / \mathrm{L})$ of Malvi, Nimari, Sahiwal and HF crossbred cattle has been presented in Table 07.

\section{Table 06}

Analysis of variance for milk density $(\mathrm{kg} / \mathrm{L})$ in Malvi, Nimari, Sahiwal and HF Crossbred cattle

\begin{tabular}{|llll|}
\hline Source of Variance & DF & MS & F-value \\
\hline Genotypes & 6 & 163.96 & $17.38^{\star *}$ \\
\hline Error & 193 & 9.44 & \\
\hline Total & 199 & & \\
\hline \multirow{2}{*}{ * Highly significant $(p<0.01)$} & & \\
\hline
\end{tabular}

Table 07

Least squares means for milk density ( $\mathrm{kg} / \mathrm{L}$ ) of different breeds of cattle at aS2-Casein (CSN1S2) gene

\begin{tabular}{|lllll|}
\hline Variants & Breeds & & & \\
\cline { 2 - 5 } & Malvi & Nimari & Sahiwal & HF crossbred \\
\hline AA & $1.03^{\mathrm{c}} \pm 0.08(22)$ & $1.04^{\mathrm{b}} \pm 0.08(31)$ & $1.03^{\mathrm{c}} \pm 0.09(50)$ & $1.04^{\mathrm{b}} \pm 0.11$ \\
& & & & $(29)$ \\
AB & $1.03^{\mathrm{d}} \pm 0.09$ & $1.05^{\mathrm{a}} \pm 0.07$ & $00 \pm 00$ & $1.04^{\mathrm{b}} \pm 0.06$ \\
& $(28)$ & $(19)$ & $(50)$ & $(21)$ \\
BB & $0.00 \pm 00$ & $0.00 \pm 0.00$ & $0.00 \pm 0.00$ & $0.00 \pm 0.00$ \\
& $(00)$ & $(00)$ & $(00)$ & $(00)$ \\
\hline Overall & $1.03^{\mathrm{c}} \pm 0.09$ & $1.04^{\mathrm{b}} \pm 0.08$ & $1.03^{\mathrm{b}} \pm 0.09$ & $1.04^{\mathrm{a}} \pm 0.08$ \\
& $(50)$ & $(50)$ & $(50)$ & $(50)$ \\
\hline
\end{tabular}

Means bearing the different superscript differ significantly $(p<0.01)$, Numbers in the parentheses denotes number of animals

The mean milk density $(\mathrm{kg} / \mathrm{L})$ was significantly higher for $A B$ genotype than AA genotype of Nimari and HF crossbred of cattle. In Sahiwal, mean milk density (kg/L) was $1.03 \pm 0.09$. The mean milk density 
$(\mathrm{kg} / \mathrm{L})$ was observed maximum in Nimari $(1.05 \pm 0.07)$ for $A B$ genotype and minimum in Malvi $(1.03 \pm 0.08)$

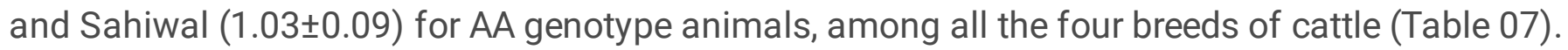

\section{Discussion}

Sequence analysis of amplicon for group specific SNP marker revealed that Adenine base at 242 base pair site in HF Crossbred replaced by Thymine in Nimari breed of cattle of Madhya Pradesh, India. In HF Crossbred at 582 base position of Adenine base is replaced by Guanine in Malvi, Nimari and Sahiwal breeds of Cattle whereas in Malvi and HF Crossbred at 715 base position of Thymine base is replaced by Cytosine in Nimari breed and 713 base position of Thymine base in Malvi and HF Crossbred is replaced by Cytosine in Sahiwal breeds of Cattle.

The mean lactose per cent was significantly higher in Malvi and non-significantly higher in Nimari and HF crossbred for $A B$ genotyped animals as compared to $A A$ genotype. Among the different genotypes of all four breeds of cattle, higher protein per cent was recorded in Nimari $(5.72 \pm 0.18)$ for $A B$ genotyped animals, while it was found significantly lower in Malvi $(4.73 \pm 0.09)$ cattle for AA genotype.

The mean SNF per cent between $A A$ and $A B$ was found non-significant in Malvi, Nimari and HF crossbred cattle. The mean SNF per cent was recorded maximum in Nimari $(8.86 \pm 0.15)$ and minimum in Malvi (7.86 \pm 0.16$)$ for AA genotyped animals, among all the four breeds of cattle. In accordance to the above findings, Szymanowska et al. (2004) showed that the AA genotype determine higher lactose and SNF per cent in Polish Black and White cattle.

The mean milk density $(\mathrm{Kg} / \mathrm{L})$ was significantly higher for $A B$ genotype than $A A$ genotype of Malvi and $\mathrm{HF}$ crossbred cattle. In Sahiwal, mean milk density $(\mathrm{Kg} / \mathrm{L})$ was $1.33 \pm 0.09$. The mean milk density per cent was observed maximum in Nimari $(1.05 \pm 0.07)$ for $A B$ genotype in Malvi among all the genotypes of all the four breeds of cattle.

In last to conclude PCR-RFLP analysis of as2-Cn gene (1267bp) with EcoRV RE revealed two genotypes viz., AA (1267/1267bp) and AB (1267/1150/117bp) in Malvi, Nimari and HF crossbred animals, whereas, only AA (1267/1267 bp) genotype was observed Sahiwal cattle. All the screened animals of Sahiwal were found monomorphic at as2-Cn/EcoRV gene locus. The tested animals of Sahiwal were found monomorphic at this locus. The genotypic and gene frequencies of aS2-casein gene (CSN1S2)/EcoRV locus pattern in Malvi, Nimari, Sahiwal and HF crossbred cattle has been showed that the frequencies of $A A, A B$ and $B B$ genotypes were found to be $0.44,0.56$ and 0.00 in Malvi; $0.68,0.32$ and 0.00 in Nimari; $1.00,0.00$, and 0.00 in Sahiwal and $0.58,0.42$ and 0.00 in HF crossbred cattle, respectively. The frequency of $A$ allele was found to be highest as compared to $B$ allele in all the four breeds of cattle under the study

Association study of different genotypes with milk composition traits revealed that the mean lactose per cent was significantly higher in Malvi and non-significantly higher in Nimari and HF crossbred for $A B$ genotyped animals as compared to AA genotype. The mean SNF per cent between AA and AB was found non-significant in Malvi, Nimari and HF crossbred cattle. The mean milk density $(\mathrm{kg} / \mathrm{L})$ was significantly 
higher for $A B$ genotype than AA genotype of Nimari and HF crossbred of cattle. The mean milk density $(\mathrm{kg} / \mathrm{L})$ was observed maximum in Nimari for $A B$ genotype and minimum in Malvi and Sahiwal for $A A$ genotype animals, among all the four breeds of cattle.

\section{Declarations}

\section{ACKNOWLEDGEMENT}

Authors are thankful to our esteemed university NDVSU, Jabalpur (M.P.) for providing necessary facilities during entire research work. The Instructional Livestock Farm Complex, College of Veterinary Science and A.H., Jabalpur Cattle breeding farm Khargone and Aagar of M.P are gratefully acknowledged for providing help during sample and data collection.

\section{Funding}

No funding to declare.

\section{Conflicts of interest}

The authors declare that there is no conflict of interest.

\section{Ethics approval}

All animal studies have been approved by the appropriate ethics committee and have therefore been performed in accordance with the ethical standards.

\section{Consent to participate}

Not Applicable

\section{Consent for publication}

Not Applicable

\section{Availability of data and material}

The authors declare that the data supporting the findings of this study are available within the article.

\section{Code availability}

Not Applicable

\section{Authors' contributions}

Both the Authors are involved in the conducting research, result interpretations, statistical analysis and paper writing. 


\section{References}

Hayes, H., Petit, E., Bouniol, C. and Popescu, P. (1993). Localization of the alpha-s2-casein gene (CASAS2) to the homologous cattle, sheep and goat chromosome 4 by in situ hybridization. Cytogenetics Cell Genetics, 64: 281-285.

John, S.W., Weitzner, G., Rozen, R. and Scriver, C.R. (1991). A rapid procedure for extracting genomic DNA from leukocytes. Nucleic Acid Research, 19 (2): 408.

Snedecor, G.W. and Cochran, W.G. (1994). Statistical method. $8^{\text {th }}$ edn. The lowa State College Press, Inc. Amer. lowa USA. 950 p.

Szymanowsky, M., Eulalia, S., Marek, L. and Lech, Z. (2004). Association of nucleotide-sequence polymorphism in the 5 '-flanking regions of bovine casein genes with casein content in cow's milk. INRAEDP Sciences, 84: 579-590.

Tamura, K., Nei, M. and Kumar, S. (2004). Prospects for inferring very large phylogenies by using the neighbor-joining method. In: Proceedings of the National Academy of sciences of the United States of America, 101: 11030-11035.

Thompson, J.D., Higgins, D.G., Gibson, T.J. and Clustal, W. (1994). Improving the sensitivity of progressive multiple sequence alignment through sequence weighting, position-specific gap penalties and weight matrix choice. Nucleic Acids Research, 22: 4673-4680.

Yeh, F.C., Yang, R.C., Boyle, T.B.J., Ye, Z.H. and Mao, J.X. (1999). Popgene 32 version 1.32, the userfriendly shareware for population genetic analysis. Molecular Biology and Biotechnology Centre, University of Alberta, Canada.

\section{Figures}

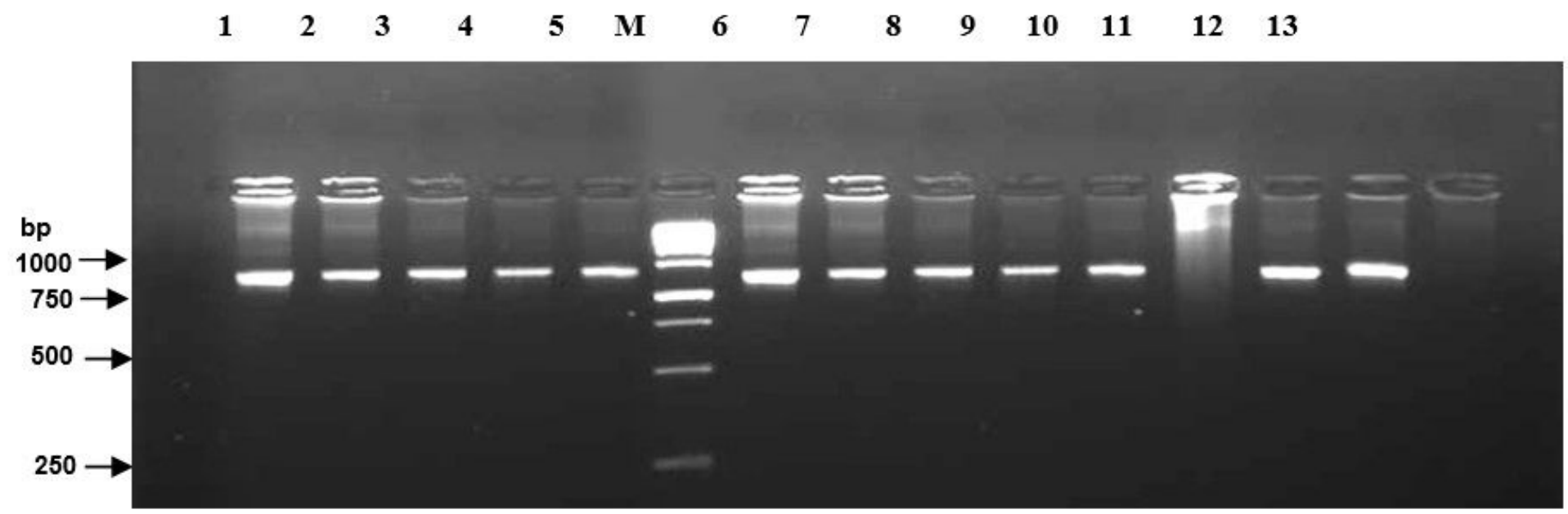

Figure 1 
Amplified PCR product of aS2 gene of Malvi cow, electrophoresed on 2\% agarose gel, M: 1000bp DNA ladder, Lanes: 1-13

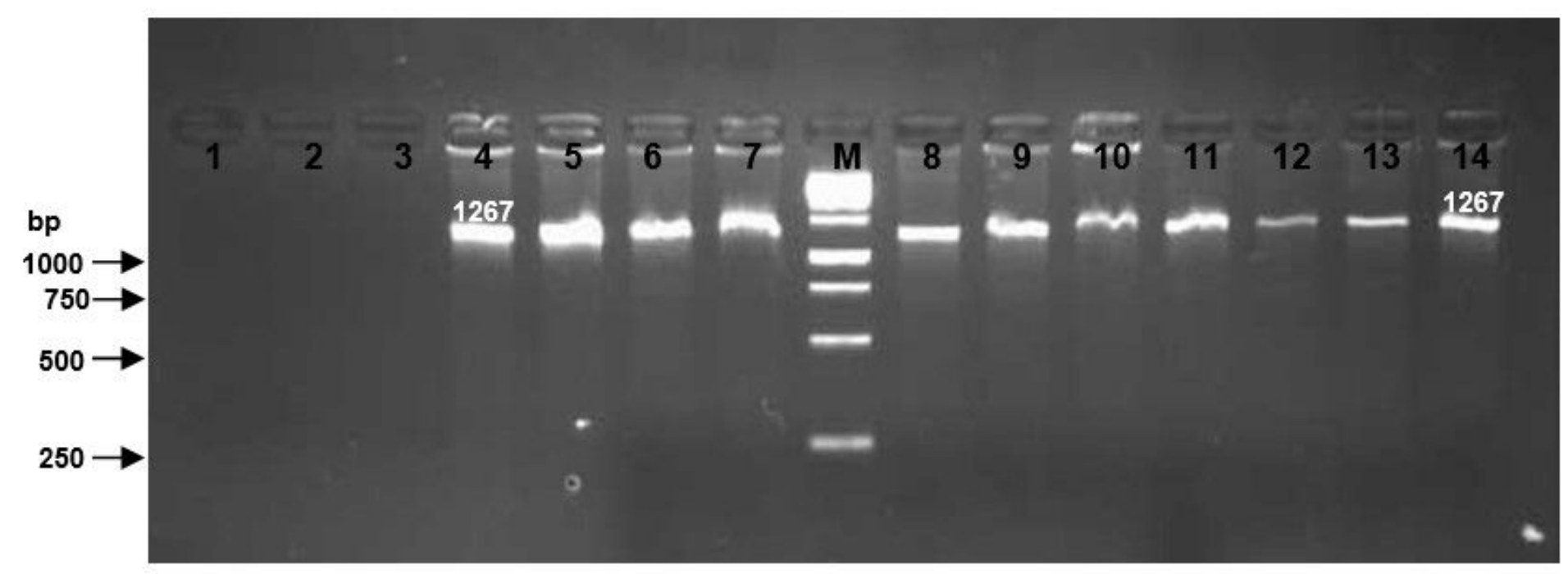

Figure 2

Amplified PCR product of aS2 gene of Nimari cow, electrophoresed on 2\% agarose gel, M: 1000bp DNA ladder, Lanes: 1-11

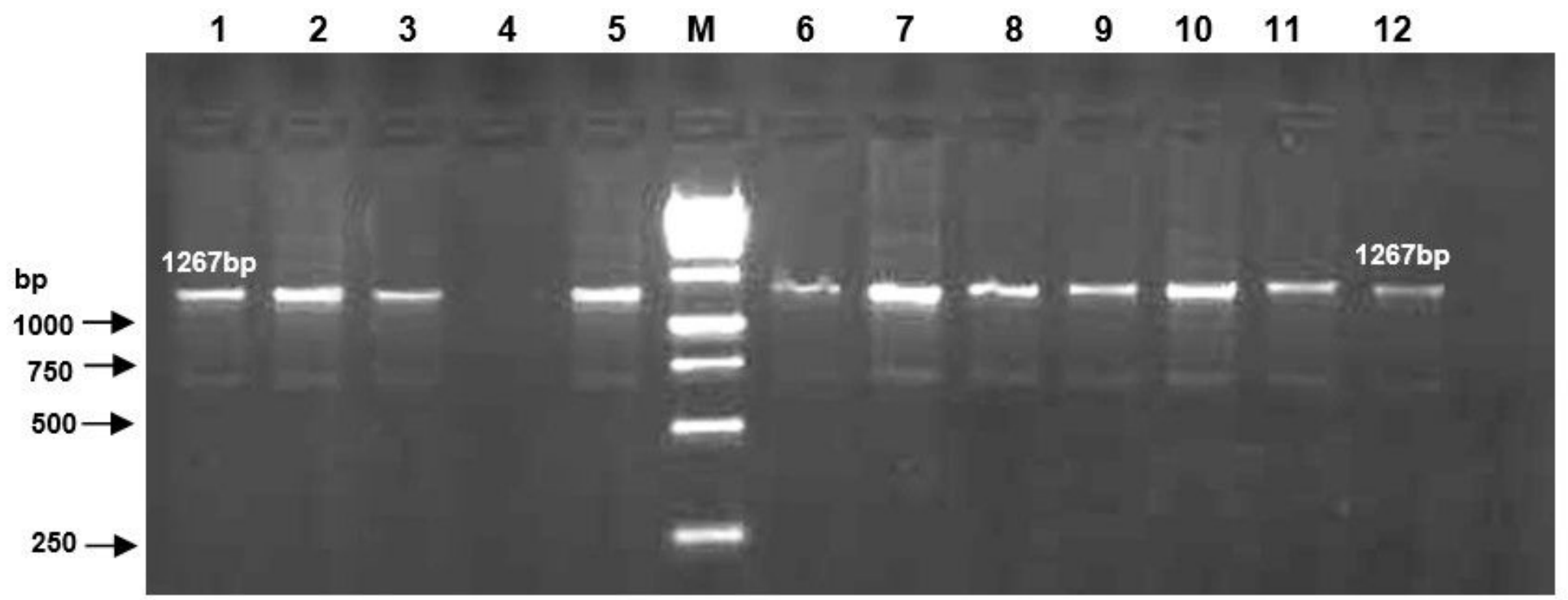

\section{Figure 3}

Amplified PCR product of aS2 gene of Sahiwal cow, electrophoresed on 2\% agarose gel, M: 1000bp DNA ladder, Lanes : 1-12 


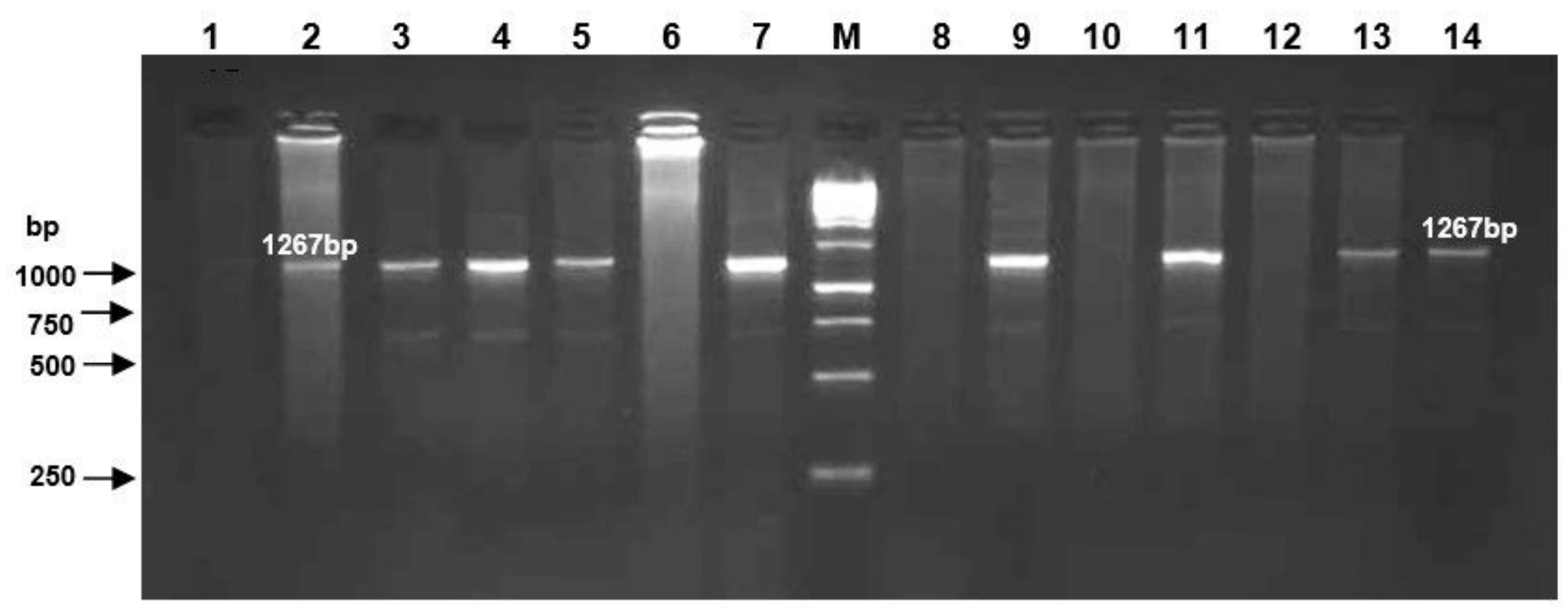

Figure 4

Amplified PCR product of aS2 gene of HF Crossbred cow, electrophoresed on 2\% agarose gel, M: 1000bp DNA ladder, Lanes: 1-14

HP-AS2 MEALUT-A.92 WTMENAT-AS2
SAHTWAL-AS?

HF-AS2

MELVI-AS2 MrMeANI-AS2
SAHINAL-AS?

HE-AS2

MEANXI-As? MTEART $-A S 2$ SAHTWAL-AS?

HF-AS2

MEAEV $x-A s 2$

SARTMESTS

HK-As2

MAEUT-AS2

NTMEAPI-AS2

SAMTWAL-AS?

HF-AS2

EALVI-AS2

TAMTRA-AS2

HF-AS2

EALVI-AS2

WroENRx-AS2
SAHTWAL-AS2

HF-AS2

EALVT-AS2

SAPTWALAS

HE-AS2

MEALVX-AS2

WTEEART-AS2
SAHTWAL-AS?

HF-AS2

GELVI-AS2

SAHTWAL-AS?

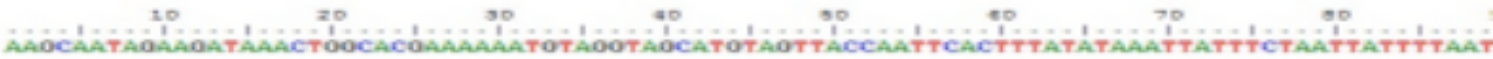

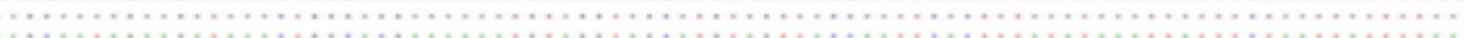

$230 \quad 2$

roó -

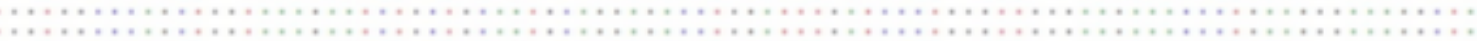

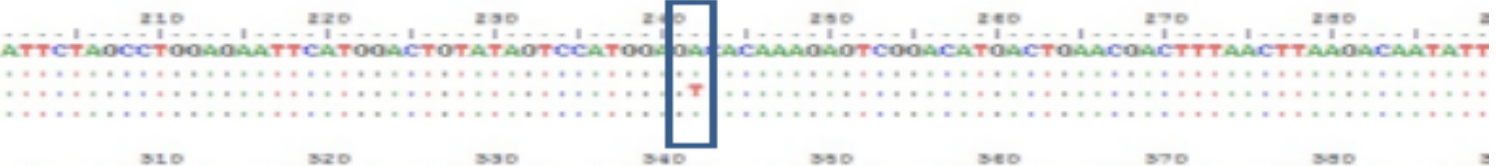

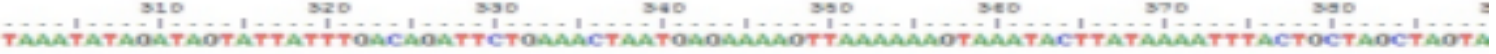

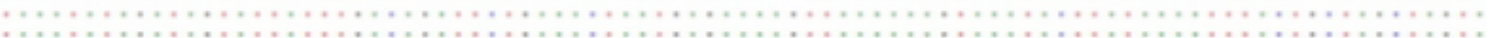
$\begin{array}{ccccccc}410 & 420 & 490 & 440 & 490 & 400 & 400\end{array}$

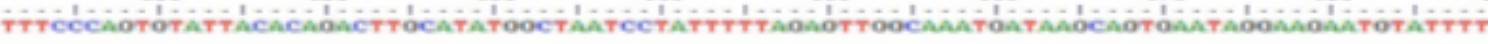

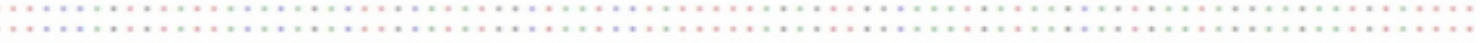
Fo 1 .

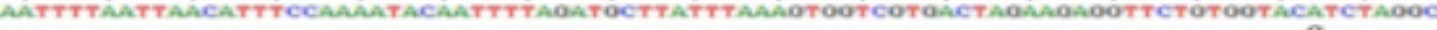

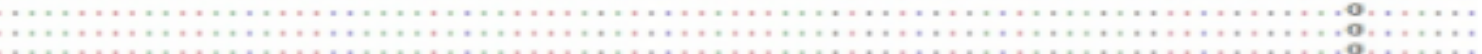

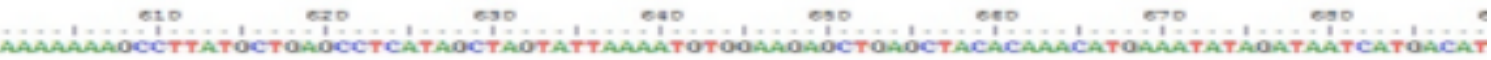

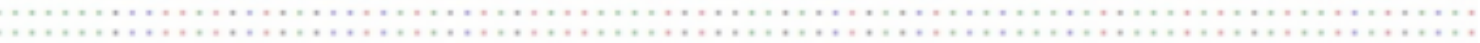

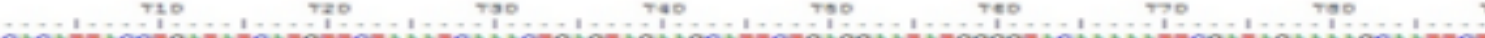

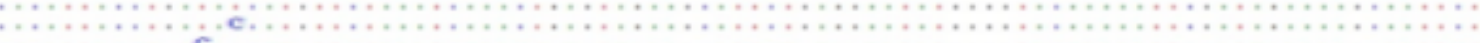

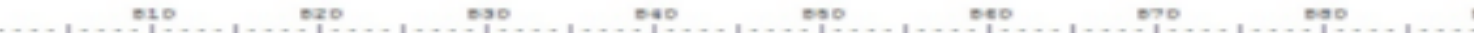

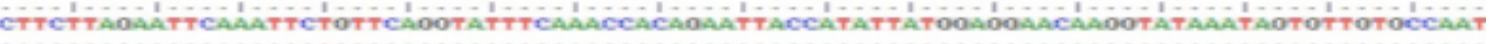

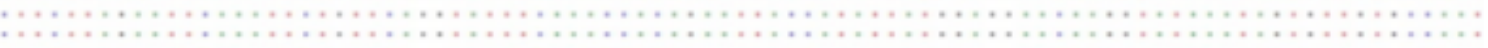

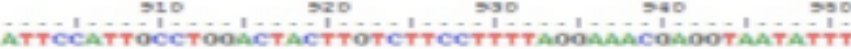

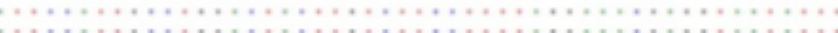
и. . . . . . . . . . . . . . . . . . . . . . . . . 
Figure 5

Sequence analysis of amplicon for group specific SNP marker

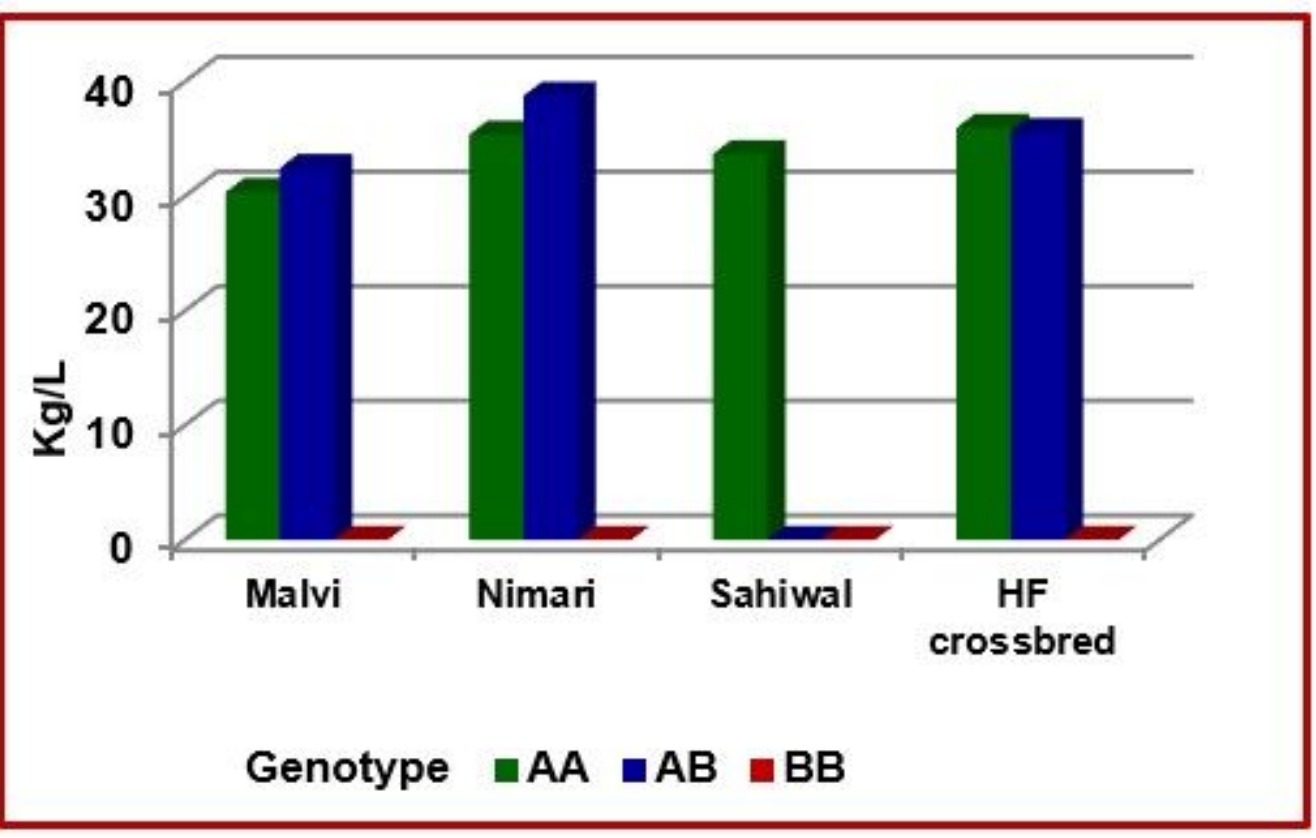

Figure 6

Graphical representations of least squares means for Lactose (\%) in the milk of different breeds of cattle at aS2-Casein (CSN1S2) gene locus.

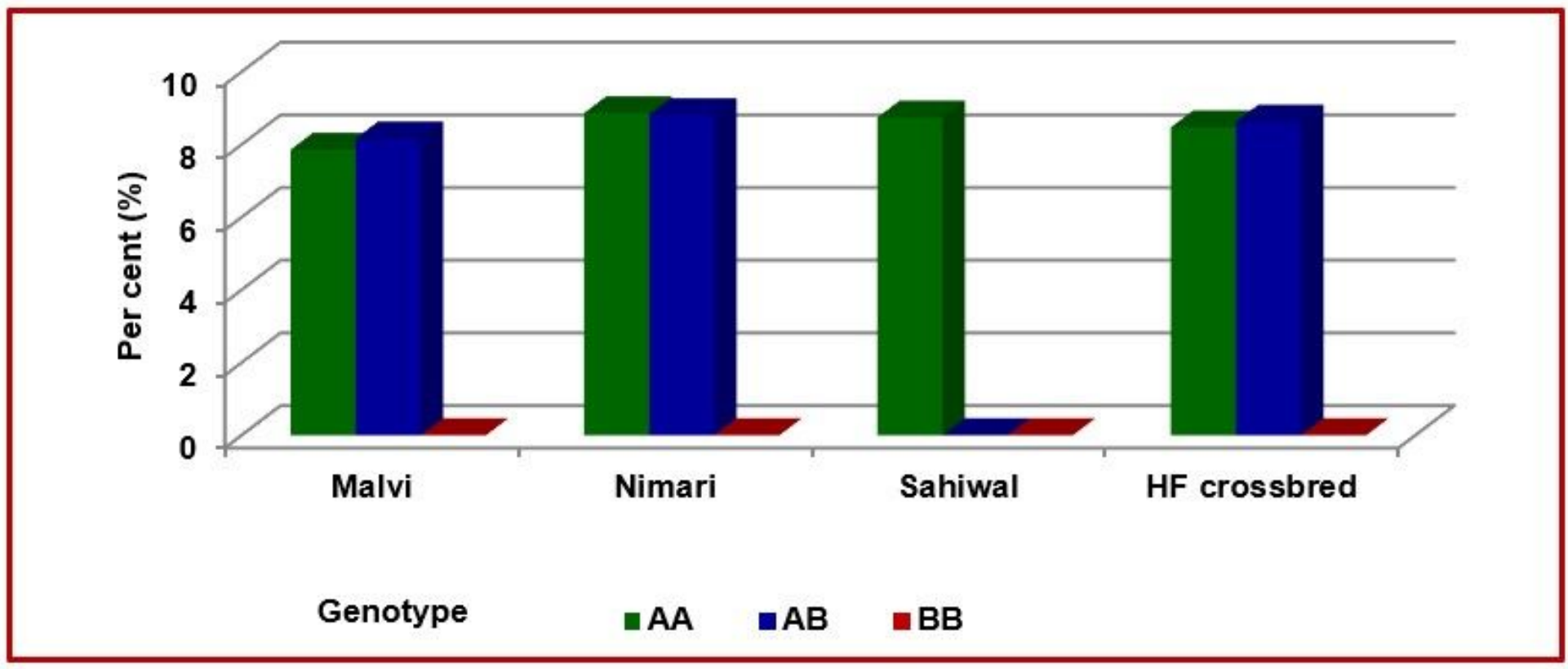

Figure 7

Graphical representation of least squares means for SNF (\%) in the milk of different breeds of cattle at aS2-Casein (CSN1S2) gene locus. 


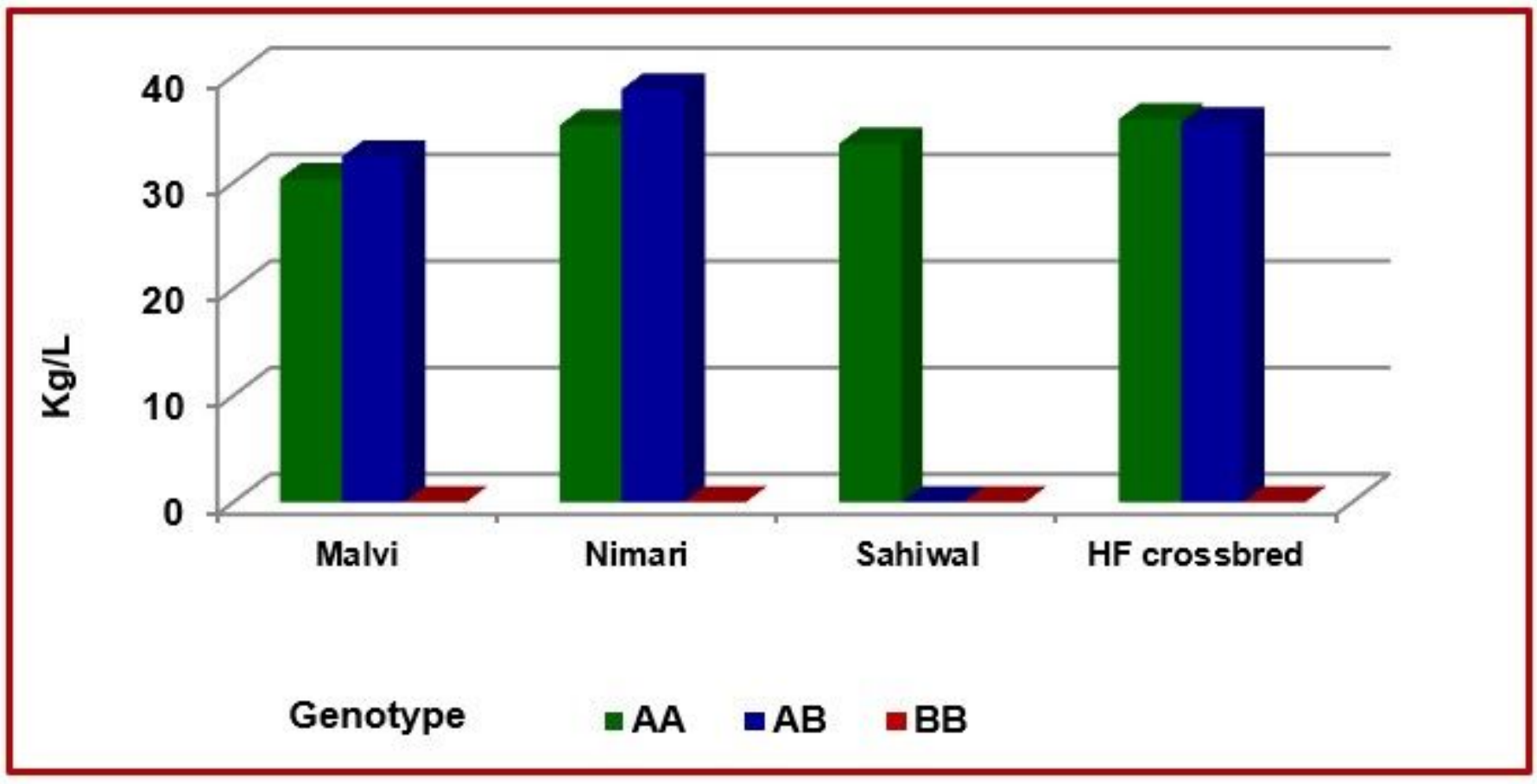

Figure 8

Graphical representations of least squares means for density $(\mathrm{kg} / \mathrm{L})$ in the milk of different breeds of cattle at aS2-Casein (CSN1S2) gene locus. 